\title{
風工学における乱流の数值シミュレーション \\ Numerical Simulation for Turbulent Flow concerned with Wind Engineering
}

池人内昌 弘 ${ }^{*}$

Masahiro IKENOUCHI
最近の数値解析法の進屡は目覚しいものであり, 従来解析困難とされ，また，実験的に再現出来な い問題にも有効几活用されるようになつてきてい る。このような中で, 風工学会でも一つのテーマ として取り上げてはとの要望があり，村上先生に パネラを批願いして，その一つの分野をまとめて いたたくことになった。乱流モデルの紹介から例 計算結果拉よび数值解析上の問題点まで含めて明 解な報告があり，乱流数值解析の解説として㫃蒙 的でもあった。

パネラの講演儿関して活発な討論が進められ， 以下にまとめて紹介する。

1）乱流モデルに関する問題で, よく使われる 2 方程式モデル( $\mathrm{k}-\varepsilon$ 法) と，LE Sのそれぞ れの特徵等について, 田村氏 (清水建設) は，2 方程式モデルでは平均的な乱れはよいが，変動量 など乱れの詳しい性状解析には十分ではないので はないかとか，LESでは，スぺクトムムピー クが出る場合があるなど細かな議論まであった。 土屋氏 (日本鋼管) からもL E S の意味などルつ いて同様な議論があり，それそれれ適用する対象に よってぞのようなモデルを使充ばよいか関心の的 となった。これらの議論に関してパネラは次のよ う炕乱流モデルの特徽をまとめている。

2 万程式モデルの特徴

(1) 工学の多くの分野で既に適用された実績を 持ち，良好な結果を得た例も多く，沉用モデ
ルとしてある程度の評価を得ている。

(2) L E S 飞比べて計算時間が短い。

(3) 欠点としては，時空間に関して大きなスケ ールの流れしか予測出来ないこと，モデルの 中に数值定数が多く，この值の妥当性に関す る吟味が不十分なこと。

L E S の特徽

(1) 乱流統計理論から考えて,モテルの内容や 根拠が明快であること。

(2) モデルの中の定数が少く沉用性が高い。

(3) 細かいスケールの時空間の変動を予測する ことが出来る。

(4) 欠点としては，2 万程式に比べ計算時間が 長いこと。

2）境界条件について，高梨氏（清水建設）, 平野氏（三井造船）から質疑があった。 f ree slip 条件について, 壁面近傍でのメッシュ分割, 格子点を粘性底層内飞取り難いことなどから妥当 な条件のようである。高梨氏から凹面のような複 雑な壁面でどう考壳ればよいか質疑があったが， 今後の問題として検討されていくことであろう。

3）風洞実験との照合について，広瀬氏（航技 研)より議論が出された。航空機の場合も，N $\mathrm{S}$ 万程式を解いた結果と実験とが合わない場合が ある由である。広瀬氏几よると，風洞実験におい ては，境界層プロフォイル，壁条件等が必ずしる 数値実験と一致しているとは言い難い。一方, 压

*三井造船昭島研究所

Aki shima Laboratory, Mitsui Eng. \& Shipbuilding Co., Ltd 
力分布が一致するようにすると, 速度や迎角が異 なっても，その他の流れ場の特性はよく一致して くる。このように両者の比較は十分注意すると共 K, 上手に比較すれば良い成果を数值実験で得ら れるのではないかとの意見があった。これらに対 し, 指摘通りである。但し, 例兄ば差分格子の大 きさによる制約等によって両者の条件を希望通り 一致させることは難しい場合が多い由, 回答があ つた。

続いて, 数值実験の乱流モデル係数は, 平衡境 界層実験にもとついていて, 非平衡, 非定常境界 層の解析には必ずしも十分ではない。より精度の 高い係数を得るよ 5 な験側の協力が今後必要で はないかとの意見があった。これについてはそ の通りで， Cs の値の影響が大きいことは，本文 中で報告してあり，更飞検討を進めている由，回 答があった。

また，田村氏からも同様にLE S 飞おけるCs の影響が大きいことから，差分スキームの工夫で 数值粘性を抑えて改良出来るのではないかとの意 見もあった。

4)メッシュ分割, 差分格子点の置き方决 ても討論があった。広瀬氏は，粘性底層をとら兄 るために翼型解析では $\Delta \mathrm{h}$ を底層内に 1 点とるよ ラにして, 剥離点の位置, 境界層分布の高精度な 解析を試みている。剥れた後の流れは，大きな渦 をとら劣ればある程度間飞合らから，物体境界近 くに格子を集中させるのも一つの方法と考光られ ないかとの意見があった。これ的いては，その 通りであるが，風工学の分野では，翼型まわりの 流れのような薄い境界層問題とは異なり，その取 り扱うスケールが大を，壁近くに多くの格子点 を設けることが困難な場合が多い由，回答された。 これは，本文中のピル風問題でも議論している。

以上, 討論は, 計算手法に関するすのが多かっ たようである。流れ場の問題として，高梨氏から 流速ベクルのふらつきや, 平野氏からカルマン
渦等の問題にも乱流モデルがそのまま適用出来る のかなどの質問があったがるう少し議論の対象 になればと思われた。

風工学で数值解析がテーマとして取り上げられ たことは有意義でありこれを機会に数值解析へ の気運が盛り上ればと願っている。航空分野では Numerical Wind Tunne1 と称する超大型計算機 システムによる空力性能設計が進展しているそう である。数値解析の進展に驚きを持たれたのが, 多くの方実感ではないかと思われるが，一方， 複雑な問題への適用にはまだ未解明な問題も多く, 対象とする問題によって乱流モデルの選定なりル 工夫が必要であり，今後の研究が期待される。パ ネラの報告にもあったように，その使い炕おい て, 流体力学的考察を踏まえながら進めることが 大切である。誤った適用の結果, 数值解析飞不当 な評価を受けることを恐れるすのである。

今回, 乱流が主題であったが，層流を含めて風 荷重, カルマン渦, 非定常空気力等についても, 別の機会に取り上げていただければと願っている。

以上，筆者の私見も交じえ報告させていただい た。ここに紹介した討論については筆者が適当に 調整したところもあり，討論者の意図を十分に反 映していないところがあればご容謝願いたい。 